\title{
The Potential of Incorporating Computer Games in Foreign Language Curricula
}

\author{
Jayakaran Mukundan (Corresponding author) \\ Department of Language and Humanities Education, Faculty of Educational Studies \\ Universiti Putra Malaysia, 43400 UPM SERDANG, Selangor, Malaysia \\ E-mail: jaya@educ.upm.edu.my \\ Seyed Ali Rezvani Kalajahi \\ Department of Language and Humanities Education, Faculty of Educational Studies \\ Universiti Putra Malaysia, 43400 UPM SERDANG, Selangor, Malaysia \\ E-mail: ali.rezvani85@gmail.com \\ Bakhtiar Naghdipour \\ Department of English Language Teaching, Eastern Mediterranean University, North Cyprus \\ E-mail: bakhtiar.naghdipour@cc.emu.edu.tr
}

Doi:10.7575/aiac.alls.v.5n.2p.19

URL: http://dx.doi.org/10.7575/aiac.alls.v.5n.2p.19
Received: $15 / 02 / 2014$

Accepted: 20/03/2014

\begin{abstract}
There is ample evidence that technology-enhanced instruction could result in students' learning. With the advancement and ever-increasing growth of technology, the use of educational electronic games or computer games in education has appealed to both educators and students. Because of their potential to enhance students' interest, motivation and creativity, computer games can be used to teach various skills and strategies to different types of students, particularly schoolchildren. These games have also made inroads into language learning classrooms as they provide language learners with a rich learning context to engage in authentic and meaningful learning experiences. This paper reviews the potential of integrating computer games into second/foreign language syllabi and curricula by offering a synopsis of the assumptions, prior studies and theoretical background in support of these games in language education. At the end, the paper touches upon the role of teachers and the likely inhibiting factors affecting the integration of computer games into English language programs.
\end{abstract}

Keywords: computer games; digital game-based learning; ESL/EFL

\section{Introduction}

The introduction of computers to the world of education has offered numerous possibilities to enhance learning and instruction. The application of electronic games in education is aligned with the necessity to change our teaching methods in order to cater for the needs of future citizens in a digital society (Gros, 2007). Sandford et al. (2006) also asserted, "incorporating computer games into learning environments, it is hoped by many, will enhance student engagement with learning" (p. 6). Although digital games are not limited to computer games, we use computer games as a generic term rather than a specific reference to those games users utilize at their computers. Console and video games, for example, are well-known games different age groups may be involved buying and using them. As some of the criteria of digital games, Prensky (2001) identified them as those rule-based games that have goals and objectives, provide feedback that includes a challenge or competition, require some sort of interaction, and represent a story. The emergence of these games in education has led to the coinage of the term 'edutainment', indicating a blending of both aspects of education and entertainment (Purdy, 2007).

The use of digital games for the new generation of learners, or 'digital natives' (Prensky, 2001), is an opportunity for deep and sustained learning (Barab, et al., 2007; Gee, 2008). Playing these games might be an indicator of computer literacy in society, as learning through computer, whither it be incidental or intentional learning, is also an ingredient of the knowledge in the new millennium. Digital game-based learning is defined as "any marriage of educational content and computer games (Prensky, 2001, p. 145), with a specific focus on the motivational aspect of these games in education. As far as second or foreign language learning is concerned, computer games can be used formally or informally to teach different components of language such as vocabulary, grammar, pronunciation and spelling. However, these games have yet to find their way into second/foreign language programs in many English as a second/foreign language (ESL/EFL) contexts. There are many reasons for this delay, including curricular barriers, teachers' inadequate computer literacy, their beliefs and perceptions of the potential of these games (Kennedy-Clark, 2011; Ketelhut \& Schifter, 2011), and a host of other variables and contextual affordances. This paper reviews several 
practical and theoretical underpinnings for integrating computer games into EFL classes, hoping that teachers treat them as an alternative to many traditional teacher-fronted learning activities in such input-poor contexts.

\section{Research Review}

Some three decades ago, Wright et al. (1984) considered computer games central to a teacher's pedagogical toolkit. These games, which are coming out in different versions and types and appeal to different age groups and students' demographics, have the potential to engage and motivate learners cognitively, emotionally, and socially (Huang, 2011; Lengeling \& Malarcher, 1997; Prenksy, 2001). Recent studies have documented the impact of educational computer games on boosting students' motivation to language learning (Connolly et al., 2012; Hainey et al., 2011; Howell \& Veale, 2009; Reinders, 2012; Squire, 2005). Indeed, the use of computer games enhances learners' interest and motivation to spend more time and make further effort towards achieving their learning goals.

Digital game-based learning can also foster a sense of community among language learners as they interact with each other and share their resources and experiences to complete a task or solve a problem. That is, these games could function as a source of developing group strategies such as cooperative and collaborative learning through creating meaningful contexts for language learning. Furthermore, employing educational computer games in foreign language programs supports advocating more recent communicative and learner-centered approaches to language learning, which emphasize the use of meaningful learning tasks and activities. As Gros (2007, p. 23) asserted, digital games "are usercentered; they can promote challenges, co-operation, engagement, and the development of problem-solving strategies". This is particularly helpful for new generation of learners who have grown up with technological advancement and computer gaming.

Since language learning classes in ESL/EFL contexts involve serious and formal atmosphere, with the teachers focusing mostly on the textbooks (Al-Issa, 2007), computer games can break the tedious routine of the traditional classroom cycle and improve the dynamics of the classroom. While a large number of these games are normally exploited for informal learning outside of schools, they "have unique affordances that make them especially useful in contentoriented, culture- and task-based foreign language curricula" (Neville, 2009, p. 47). Also, digital game-based learning "has positive effects on students' comfort level, sense of self-efficacy, and knowledge transfer and retention" (Neville et al., 2009, 47). A fiction game, for example, can help second or foreign language learners develop their reading abilities (Neville, 2009). Moreover, commercial computer games were found to affect incidental (Thorne et al., 2012) and intentional L2 vocabulary learning (Cobb \& Horst, 2011; Ranalli, 2008). Besides helping language learners to develop their vocabulary, pronunciation, and listening skills, computer games can also be a hot topic or an ideal context for group discussions, which could result in fostering communicative strategies and speaking skills. Yu et al. (2002) reported that incorporating electronic games into language learning classes increased students' overall satisfaction with the learning experience.

Most importantly, because the growth of technology has increased the informal and incidental learning among children, the use of electronic games can enhance their motivation and confidence in learning a second or foreign language. Anyaegbu et al. (2012), for example, found that integrating computer games in ES:/EFL classes at primary schools in China motivated, engaged, and piqued schoolchildren's interest in learning English. Supplementing these games also lowered students' anxiety, helping them retain more vocabulary and develop their pronunciation and other language learning skills. Even, some scholars (e.g., Denner, Werner \& Ortiz, 2012; Ke, 2014; Mayer \& Wittrock, 2006) have proposed and applied game-design as a means of teaching students problem-solving and higher-order thinking skills because these are the most neglected areas in formal education in many contexts. Such games have been found to develop visual literacy such as the ability to read pictures and diagrams (Gros, 2007). In addition, they helped students develop divided visual attention or the skill of responding or attending to different stimuli at the same time (Greenfield, 1996).

\section{Computer games and learning theories}

Behaviorism views learning as a change in behavior realized through repetition and reinforcement of desired actions (Gagné \& Briggs, 1979). Immediate correction, rewarding good habits and discouraging bad habits were other features of resorting to the principles of behaviorism in language learning classrooms. Skinner's emphasis on reinforcement to strengthen behavior led to the use of mechanical devices, which resulted in the emergence of computer or electronic games in today's world of education (Lombardi, 2011). The focus of educators on programmed instruction through presenting content, providing opportunities for practice, and offering feedback resulted in the domination of behaviorist principles in computer-assisted language learning (Beaty, 2003). Thus, educational computer games emerged to teach grammar, vocabulary, and spelling through designing drills that used scores to reward or punish users or language learners (Filsecker \& Bündgens-Kosten, 2012). However, the drill-and-practice games have been criticized for promoting rote learning and lower levels of knowledge (Jonassen \& Howland, 2003). The first generation of educational computer games or what were dubbed 'edutainment' contained repetitive and poorly designed tasks that failed to support progressive understanding (Egenfeldt-Nielsen, 2005). These games, such as Mingoville's mini-games, ignored the role of teachers, social interaction and reflection in learning (Filsecker \& Bündgens-Kosten, 2012). These shortcomings were the reasons for the production of other generation of computer games.

The use of educational computer games are also supported by 'the affective filter hypothesis', which suggests that negative emotions such as higher levels of anxiety and boredom might function as a filter that interferes with receiving second language input (Krashen, 2003). For example, some researchers (e.g., Atake, 2003; Deesri, 2002) reported that 
integrating computer games into syllabus lowered students' stress and kept their attention throughout the lesson. That's why the new generations of digital games, which strongly support the idea of games in education, demand that these games be designed in a way to engage gamers in comprehensible input; one that is not too much beyond their proficiency level. Likewise, the syllabus content based on Krashen's theory for young learners should include games, dialogues and leisure activities that native speakers of a language would do in natural situations. Although conventional wisdom might suggest that game-based learning lower learners' anxiety level and enhance their self-confidence, it seems that lowering affective filter depends on the type of learners, their age, gender, and cultural background.

As another supportive theory for the effect of digital game-based learning on language learners, multiple intelligence theory espouses the use of computer games, especially in the form of a blending of video and audio, to serve a variety of learning styles and to maximize the chances of meeting the needs of different types of learners (see Gee, 2007). These games can give language learners alternatives to benefit from multimedia applications. For example, they can cater for language learners' linguistic intelligence while they listen to or even hear words and linguistic input on the screen. Additionally, computer games can attract learners with logical-mathematical intelligence as they involve learners in problem-solving activities. Game players are also engaged in viewing visual images and reading materials to entertain their visual intelligence. Additionally, learners with interpersonal and intrapersonal intelligences are attracted by electronic games, providing them with opportunities to interact with the virtual players, themselves or other fellow players.

In addition, advocates of constructivism have tried to harness the potential of computer games in education. Contrary to behaviourist education, they believe that students should construct knowledge on their own (Jong et al., 2010). Following other principles of constructivism, computer games have focused on motivating learners, increasing their problem-solving or cognitive abilities, and improving their interaction with others in an authentic and stress-free environment (Gee, 2005; Jong et al., 2010; Mason \& Moutahir, 2006; Shaffer, 2006). In particular, game-like activities could foster creativity, motivation, and deep learning (Piaget, 1970), as students tend to spend more time and energy on these activities. Furthermore, these games are socially and culturally situated (Gee, 2003), allowing gamers to participate, compete and collaborate with others (Prensky, 2001). This is especially important for language learners, who need to engage in discussing, sharing, interacting with each other to increase their opportunity to use language purposefully. Constructivists also support learner-centered approaches to language learning and situate learning tasks in a problem-solving framework where learners have to engage in a meaningful effort to work out linguistic or nonlinguistic problems. The second generation of computer games followed a cognitive-based or constructivist approach, taking into account learners' previous experiences and background (Egenfeldt-Nielsen, 2005). As another feature of cognitive-based approach, previous research reported that compared with traditional school tasks computer-based learning can enhance children's concentration on the instructional and learning activities (Clarfield \& Stoner, 2005; Ota \& DuPaul, 2002).

Computer games are also a natural way individuals exploit to socialize, communicate and use language meaningfully within their community. From a socio-cultural perspective, computer games, especially video games, are used to construct sustainable language learning experiences, which are themselves affected by the contextual factors such as culture and the learners' identity. For example, Gee (2003) argued that video games offer learners ways to interpret semiotic domains, develop their agency and autonomy, promote their interaction with others, and help them with different audiovisual learning experiences. Additionally, they can foster learners' communicative competence by providing opportunities for meaningful interaction with the game world. In particular, video games invest in the role of context of the game, actors, the scenario, actors' dialogue, and their experiences and culture, while respecting linguistic and cultural diversity (McGonigal, 2011). The third generation of computer games has thus far focused on this broader social context in which learners have more room for interaction and action. Both leaners and teachers are deemed important in this approach and teachers act as facilitators and scaffold to learners as well as to the whole learning process (Egenfeldt-Nielsen, 2005). Learners can then share socio-cultural values with others and build a strong identity through engaging with other members of this virtual context. This is crucial as far as language learning is concerned because electronic games have a social nature that justifies their use for foreign language learning, which is itself another social phenomenon (Young et al., 2012).

\section{The role of teachers}

Undoubtedly, the role of teachers in selecting a particular type of game or employing them for a specific type of activity or strategy is undeniable. Computer games are a source of linguistic input for language learners, as they include audio and text, which might vary in volume and quality depending on the type of the game and language learners. Therefore, language teachers should choose the most appropriate and effective games in order to achieve a learning goal or use them as reinforcement for a newly taught area of language learning. These educators, as Lombardi (2013) call them, are "actors, who use their cognitive and intellectual resources to discover, understand, process and eventually learn" (p. 139). A language educator, therefore, should constantly challenge her skills and reevaluate her role to keep up with the technological advancement in order to better accommodate learners' needs. Lombardi (2013) maintains, "the language educator is able to perform as a techno-educator, for both students and colleagues" (p. 141). In other words, language educators not only should know how to harness the educational potential of digital games, but should also be cognizant of different issues, such as technical and cultural, involved in introducing these games in a given context. They are resourceful teachers who may use computer games in various ways: as a formal teaching strategy, as an informal learning strategy, or as a remedial activity for those students lagging behind others. 
Regarding the necessary requirements to subscribe to the digital game-based learning, teachers' level of access to computer games and their beliefs about the effectiveness of these games were considered as two main predictors of their successful implementation in language learning classrooms (Proctor \& Marks, 2013). Similarly, Ketelhut and Schifter (2011) found out that teachers' adoption of computer games depended on their perception of efficacy of using these games. However, while pre-service teachers reported that using computer games can help students visualize better and actively participate in their learning (Kennedy-Clark, 2011), a majority of them reported having very little experience with educational electronic games (Schrader et al., 2006). This finding suggests that the role of teacher training and teachers' expertise in technological know-how can increase students' benefit from these games. As an example, if teachers know how to expand their scope, computer games can entertain and, at the same time, educate language learners (Egenfeldt-Nielsen, 2007); otherwise, digital games that do not include teacher as the facilitator in the process of this type of learning dominate the markets (Ketamo et al., 2013).

However, if teachers lag behind the new developments and trends in digital game-based learning, teacher education programs and courses should intervene by expanding the curriculum to maximize teachers' awareness of this potential and help them meet the new methodological challenges in language pedagogy (Caon, 2006). Teacher educators should also promote different types of knowledge in pre-service teachers because "game-based learning requires the careful orchestration of different knowledge domains" (Bourgonjon, 2013, p. 32). Through developing their professional knowledge in different areas, teachers prepare to embrace the opportunity of integrating computer games in their classes become advocating technology-enhanced learning has become a reality rather than a choice. Indeed, today's language learning classes are not only a place for learning languages but also a cradle for learning life skills and computer literacy programs.

\section{Concluding remarks}

Despite the difficulties involved in incorporating computer games into language learning curricula such as measuring the learning outcomes of these activities against the traditional measurements of learning performances, it seems that the use of these games can be taken into account as a supplement to the mainstream instructional tasks to mitigate the negative impacts of tedious traditional learning activities. Educational authorities and computer game designers can, therefore, invest in promoting these games for the benefit of the next generations of young language learners who are more wired to the use of technology and who play games for their cognitive and emotional growth as well as for discovering the surrounding world. Although language learners might use these games to avoid studying, teachers should be aware of the fact that they cannot avoid incorporating a learning strategy or practice because of its likely negative impacts. Thus, "instead of complaining about computer games detracting from education, perhaps it is time that we roll up our collective sleeves and leverage this powerful and popular technology platform for teaching foreign languages and culture" (Neville, 2009, p. 51).

However, there are several issues associated with digital game-based learning or the use of educational computer games. While educational game designers can design multimedia applications that enhance students' engagement and interest in learning activities, interest and motivational appeal of computer games may be short-lived (Hidi \& Renninger, 2006), and they may contain violent and misogynistic content or themes (Gros, 2007). Thus, the designers and educators should use those games that students are familiar with and are appropriate in terms of their content. Among other inhibiting factors to the successful implementation of educational digital games are logistical problems, inflexibility of curriculum, and teachers' insufficient professional development (Baek, 2008; Rice, 2007). By the same token, learners' factors, such as their language proficiency level, age, gender, ethnicity and their social or cultural background, can influence the implementation of these games (Gros, 2007). Therefore, teachers should make informed decisions regarding the employment of these games in a particular educational context and with a particular type of language learners. For example, integrating educational electronic games into language learning programs should be introduced from an early age and the difficulty level of these games should be adapted to students' proficiency level and ability in order to maximize their effectiveness (Hsieh \& Wang, 2008).

Given all this, it seems that adequate time and effort should be spent initiating students and teachers into the world of digital game-based learning or educational computer games. Fostering relevant abilities and procuring necessary resources are of prominent importance to ensure the efficient and effective use of these games for a specific purpose (Borg, 2003). In many cases, for example, implementing these games in an educational institution or context needs demonstration and briefing sessions in order to guarantee their optimal impact. Teachers' reflective practices, their pedagogical content knowledge, and their prior experiences are among other provisions that could help them come up with new and innovative approaches to integrating or supplementing computer games in their classes.

\section{References}

Al-Issa, A. (2007). An ideological discussion of the implications of implementing a "flexible" syllabus for ESL policy in Sultanate of Oman. RELC Journal, 38(2), 199-215.

Anyaegbu, R., Ting, W., \& Li, Y. (2012). Serious game motivation in an EFL classroom in Chinese primary school. The Turkish Online Journal of Educational Technology, 17(1), 154-164.

Atake, K. (2003). Using games to teach English in Japanese junior high school. Retrieved February 10, 2014, from ERIC database. (ERIC Document Reproduction Service No. ED479748) 
Baek, Y. K. (2008). What hinders teachers in using computer and video games in the classroom? Exploring factors inhibiting the uptake of computer and video games. CyberPsychology \& Behavior, 11(6), 665-671.

Barab, S. A., Sadler, T. D., Heiselt, C., Hickey, D., \& Zuiker, S. (2007). Relating narrative, inquiry, and inscriptions: supporting consequential play. Journal of science education and technology, 16(1), 59-82.

Beaty, K. (2003). Teaching and researching computer-assisted language learning. Harlow: Pearson Education.

Borg. S. (2003). Teacher cognition in language education: A review of research on what language teachers think, believe, and do. Language Teaching, 36, 81-109.

Bourgonjon, J., De Grove, F., De Smet, C., Van Looy, J., Soetaert, R., \& Valcke, M. (2013). Acceptance of GameBased Learning by secondary School Teachers. Computers \& Education 67, 21-35.

Caon, F. (2006). Pleasure in Language Learning. A Methodological Challenge. Perugia, Italy: Guerra.

Clarfield, J., \& Stoner, G. (2005). The effects of computerized reading instruction on the academic performance of students identified with ADHD. School Psychology Review, 34(2), 246-254.

Cobb, T., \& Horst, M. (2011). Does word coach coach words? CALICO Journal, 28(3), 639-661.

Connolly, T. M., Boyle, E. A., MacArthur, E., Hainey, T., \& Boyle, J. M. (2012). A systematic literature review of empirical evidence on computer games and serious games. Computers and Education, 59(2), 661-686.

Deersi, A. (2002). Games in the ESL and EFL class. The Internet TESL Journal, 9(9).

Denner, J., Werner, L., \& Ortiz, E. (2012). Computer games created by middle school girls: can they be used to measure understanding of computer science concepts? Computers \& Education, 58(1), 240-249.

Egenfeldt-Nielsen, S. (2005). Beyond edutainment: Exploring the educational potential of computer games. (Unpublished Doctoral dissertation). IT-University of Copenhagen.

Egenfeldt-Nielsen, S. (2007). The Educational Potential of Computer Games. New York: Continuum Press.

Filsecker, M., \& Bündgens-Kosten, J. (2012). Behaviorism, Constructivism, and Communities of Practice: How pedagogic theories help us understand game-based language learning. In H. Reinders (Ed.), Computer Games in Language Learning and Teaching (New Language Learning and Teaching Environments) (50-69). Palgrave Macmillan.

Gagné, R. M., \& Briggs, L. J. (1979). Principles of Instructional Design. New York: Holt, Rinehart and Winston.

Gee, J. P. (2003). What video games have to teach us about learning and literacy. New York: Palgrave Macmillan.

Gee, J. P. (2005). What would be a state of the art instructional video game look like? Retrieved February 25, 2014, from http://www.ics.uci.edu/ wscacchi/GameLab/Recommended\%20Readings/Gee-InstructionalVideoGame$\underline{2005 . p d f}$

Gee, J. P. (2007). Good video games + good learning: Collected essays on video games, learning, and literacy. New York, NY: Peter Lang.

Gee, J. P. (2008). What video games have to teach us about learning and literacy. Houndsmills, Basingstoke, Hampshire, United Kingdom: Palgrave Macmillan.

Greenfield, P. M. (1996). Video games as cultural artifacts. In P. M. Greenfield \& R. R. Cocking (eds.), Interacting with video (pp. 35-46). Norwood: NJ. Ablex Publishing.

Gros, B. (2007). Digital Games in Education: The Design of Games-Based Learning Environments. Journal of Research on Technology in Education, 40(1), 23-38.

Hainey, T., Connolly, T., \& Boyle, L. (2011). Arguing for multilingual motivation in web 2.0: An evaluation of a large-scale european pilot. In P. Felicia (Ed.), Improving learning and motivation through educational games: multidisciplinary approaches (pp. 240-260). Hershey: Idea Group Reference.

Hidi, S., \& Renninger, K. A. (2006). The four-phase model of interest development. Educational Psychologist, 41(2), $111-127$.

Howell, S., \& Veale, T. (2009). Designing serious games with linguistic resources. In Proceedings of the 4th International Conference on Foundations of Digital Games. Orlando, Florida: ACM.

Hsieh, H.-M., \& Wang, L.-L. (2008). A fuzzy approach to generating adaptive opponents in the dead end game. Asian Journal of Health and Information Sciences, 3(1-4), 19-37.

Huang, W. H. (2011). Learners' motivational processing and mental effort investment in an online game-based learning environment: A preliminary analysis. Computers in Human Behavior, 27, 694-704.

Jonassen, D. H., \& Howland, J. (2003). Learning to solve problems with technology: A constructivist perspective. Upper Saddle River, N.J.: Merrill Prentice Hall.

Jong, M. S., Shang, J., \& Lee, F. (2010). Constructivist Learning Through Computer Gaming. In M. Syed (Ed.), Technologies Shaping Instruction and Distance Education: New Studies and Utilizations (pp. 207-222). Hershey, PA: Information Science Reference. 
Ke, F. (2014). An implementation of design-based learning through creating educational computer games: a case study on mathematics learning during design and computing. Computers \& Education, 73(1), 26-39.

Kennedy-Clark, S. (2011). Pre-service teachers' perspectives on using scenario-based virtual worlds in science education. Computers \& Education, 57(4), 2224-2235.

Ketamo, H., Kiili, K., Arnab, S., \& Dunwell, I. (2013). Integrating games into the classroom: towards new teachership, in S. de Freitas, M. Ott, M.M. Popescu \& I. Stanescu (Eds.), New Pedagogical Approaches in Game Enhanced Learning: Curriculum Integration (pp. 114-135). IGI Global.

Ketelhut, D., \& Schifter, C. (2011). Teachers and game-based learning: improving understanding of how to increase efficacy of adoption. Computers \& Education, 56(2), 539-546.

Krashen, S. (2003). Explorations in Language Acquisition and Use. Portsmouth: Heinemann.

Lengeling, M., \& Malarcher, C. (1997). Index cards: A Natural resource for teachers. ET Forum, 35(4), 42.

Lombardi, I. (2013). 'Updating' language teachers: language educators, techno educators, edurectors. OLBI Working Papers, 5, (Language Education Technologies).

Lombardi, S. M. (2011). Internet Activities for a Preschool Technology Education Program Guided by Caregivers. (Unpublished Doctoral dissertation). North Carolina State University.

Mason, H., \& Moutahir, M. (2006). Multidisciplinary experiential education in Second Life: A global approach. In J. Kemp \& D., Livingstone (Eds.), Proceedings of the Second Life Education Workshop at the Second Life Community Convention (pp. 30-34). San Francisco.

Mayer, R. E., \& Wittrock, M. C. (2006). Problem solving. In P. A. Alexander \& P. H. Winne (Eds.), Handbook of educational psychology (pp. 287-303). Mahwah, NJ: Lawrence Erlbaum Associates.

McGonigal, J. (2011). Reality is Broken. Why Games Make Us Better and How They Can Change the World. New York, NY: Penguin Press.

Neville, D. (2009). In the classroom: Digital game-based learning in second language acquisition. The Language Educator 4(6), 47-51.

Neville, D., Shelton, B., \& McInnis, B. (2009). Cybertext redux: Using DGBL to teach L2 vocabulary, reading, and culture. Computer Assisted Language Learning, 22(5), 409-424.

Ota, K. R., \& DuPaul, G. J. (2002). Task engagement and mathematics performance in children with attention-deficit hyperactivity disorder: effects of supplemental computer instruction. School Psychology Quarterly, 17(3), $242-257$.

Piaget, J. (1970). Science of education and psychology of the child. New York: Oxford University Press.

Prensky, M. (2001). Digital game-based learning. New York: McGraw Hill.

Proctor, M., \& Marks, Y. (2013). A survey of exemplar teachers' perceptions, use, and access of computer-based games and technology for classroom instruction. Computers \& Education, 62, 171-180.

Purdy, J. A. (2007). Getting educational about digital games in learning. Corporative University Journal, 1, 3-6.

Ranalli, J. (2008). Learning English with The Sims: exploiting authentic computer simulation games for L2 learning. Computer Assisted Language Learning, 21(5), 441-455.

Reinders, H. (2012). Digital games in language learning and teaching. Houndmills, Basingstoke, Hampshire RG21 6XS: Palgrave Macmillan.

Rice, J. W. (2007). New media resistance: Barriers to implementation of computer video games in the classroom. Journal of Educational Multimedia and Hypermedia, 16(3), 249-261.

Sandford, R., Ulicsak, M., Facer, K., \& Rudd, T. (2006). Teaching with games: Using commercial off-the-shelf computer games in formal education. Bristol: Futurelab.

Schrader, P. G., Zheng, D., \& Young, M. (2006). Teachers' perceptions of video games: MMOGs and the future of preservice teacher education. Innovate: Journal of Online Education, 2(3).

Shaffer, D. W. (2006). How computer games help children to learn. New York: Palgrave Macmillan.

Squire, K. D. (2005). Changing the game: what happens when video games enter the classroom? Innovate. Journal of Online Education, 1(6).

Thorne, S. T., Fischer, I., \& Lu, X. (2012). The semiotic ecology and linguistic complexity of an online game world. ReCALL, 24(3), 279-301.

Wright, A., Betteridge, D., \& Buckby, M. (1984). Games for language learning. Cambridge: CUP.

Young, M., Slota, S., Cutter, A., Jalette, G., Mullin, G., Lai, B., Simenoi, Z., Tran, M., \& Yukhymenko, M. (2012). Our princess is in another castle: a review of trends in serious gaming for education. Review of Educational Research, $82,61-89$.

Yu, F. Y., Chang, L. J., Liu, Y. H., \& Chan, T. W. (2002). Learning preferences towards computerised competitive modes. Journal of Computer Assisted Learning, 18(3), 341-350. 